\title{
LIETUVOS BAZINIO KARININKŲ RENGIMO KVALIFIKACIJOS KAITA 4-OSIOS PRAMONĖS REVOLIUCIJOS PLĖTROS SĄLYGOMIS
}

\author{
Laurynas Česūnas \\ Generolo Jono Žemaičio Lietuvos karo akademija
}

\begin{abstract}
Anotacija. Publikacijos tikslas - atskleisti bütinus bazinio karininku kvalifikacijos struktūros ir turinio pokyčius, kylančius dèl veiklos procesu skaitmenizacijos ir kitu 4-osios pramonès revoliucijos (angl. Industry 4.0) aspektų. Straipsnyje aptariamos karininku švietimo ir rengimo kaitos priežastys, pristatomas karininku švietimo politikos modelis, kurio pirminè ìvestis yra ,kylančios grèsmès“", pagrindžiama, kad visi keturi karininku švietimo politikos modeliai - „Jena“, „Folklandas“, „, Kosovas“ ir „,Nacionalinio gynybos universiteto“ - atsirado kariuomenèms susidūrus su grèsmèmis. Visi pokyčiai dažniausiai buvo reaktyvaus pobūdžio. Straipsnyje aptariama squvoka „, 4-oji pramonès revoliucija“ ir kitos, nurodomi 4-osios pramonès revoliucijos požymiai: greitas internetas, galingi jutikliai, dirbtinis intelektas, kibernetinès ir fizinès sistemos, kiti sudedamieji ir jungiamieji elementai. Sparčiai vystantis technologijoms ir atrandant vis naujus ju derinius, galimas grèsmiu ir galimybiu mastas nèra plačiai ịvertinamas, todèl būsimus karininkus reikètu pradèti ruošti naujiems iššükiams jau dabar. Empirinè straipsnio dalis remiasi kariu (puskarininkiu, karininku), tarnaujančiu ir išejusiu ì atsarga, nuomoniu tyrimu, kuris buvo atliktas $2021 \mathrm{~m}$. Generolo Jono Žemaičio Lietuvos karo akademijoje. Atliekant duomenu analize taikytas turinio analizès metodas. Analizuojant buvo išskirtos ju kategorijos ir reikšmingos subkategorijos. Tyrimo metu nustatyta, kad bazinio karininku rengimo programos struktūra ir turinys nuolatos kinta, atliekami oficialūs ir neoficialūs keitimai, vieni pokyčiai vyksta keičiant programas, kiti - bandant prisitaikyti prie esamos realios situacijos. Informantai atskleide šešis veiksnius, lemiančius programu pokyčius. Visi šie pokyčiai, manytina, yra reakcinio pobūdžio. Apklausos metu nebuvo gauta ịrodymu, kad programu pokyčiai atsirado dèl naujuju technologiju skvarbos. Tyrimo metu visi informantai pateike technologiniu inovaciju taikymo Lietuvos kariuomeneje pavyzdžių. Dauguma informantu teigè, kad Lietuvos kariuomenejje (toliau - LK) yra plačiai naudojami dronai ir jie keičia karyba, tačiau formalaus kurso, kurio metu būtų supažindinama su šios rūšies technikos priemonèmis, rengiant būsimus karininkus, nèra. Informantai patvirtino, kad pastebi naujų technologijų skvarba LK, taip pat jaučia poreiki keisti ir papildyti būsimy karininku ugdymo turinị taip, kad jie igytu šiuolaikiška technologini pasirengima. Taip pat akcentuota, kad būtina suvienyti akademinio ir karinio ugdymo darbuotoju pastangas ir ieškoti sinergijos rengiant visapusiškai išprususius būsimus karininkus.
\end{abstract}

Reikšminiai žodžiai: karininkas, atsargos karininkas, bazinis karininku rengimas, kvalifikacija, pramonès revoliucija, karinis rengimas. 


\section{Ivadas}

Nuolat kylančios naujos grèsmès, kintanti saugumo aplinka, konceptualūs karinių konfliktų, kariavimo pokyčiai, technologijų pažanga suponuoja nacionalinès saugumo ir gynybos politikos, kuri kartu keičia karininkų švietimo ir rengimo reikalavimus, pokyčius. Tačiau visa tai prisideda prie nuolatinio kariuomenès personalo mokymo ir švietimo politikos, kuri yra viena pagrindinių priemonių, padedančių užtikrinti kariuomenès funkcionalumą besikeičiančioje aplinkoje, plètros. Kariuomenejje ịprasta, kad pokyčiai inicijuojami tada, kai kyla poreikis kažką keisti, remiantis igyta patirtimi - išmoktomis pamokomis (angl. leasons learned). Tai - organizacijos mokymas, kuris leidžia ịteisinti pokyčius, lemsiančius geresnius rezultatus ateityje (Joint Analysis \& Lessons Learned Centre, 2016). Karininku švietimo ir rengimo paradigmos pasikeitimą dažnai lemia neigiama karinè patirtis, atskleidžianti kariuomenès nesugebèjimą atlikti savo užduočių pasikeitusioje taktinejje, operacinejje ir strategineje aplinkoje. Tai daro įtaką reakcinei karininkų rengimo politikai (Foot, 2001). Karininkų švietimo ir rengimo turinys keičiamas tik tada, kai ,išmokstama pamoka“. Foot, ịrodydamas savo požiūrị, atskleidžia tris karininkų švietimo ir rengimo modelius, kurie yra labiau iliustraciniai nei galutiniai ir apibūdinantys dviejų šimtų metų istorijos tarpsnį Europoje. Jie ịvardyti konfliktų pavadinimais, pabréžiant tuo metu susiklosčiusias strategines aplinkybes: „Jenos“, „Folklando“, „Kosovo“. Melnikovas (2019), išnagrinèjęs keturis karininkų švietimo modelius (Foot, 2001; Libel, 2019), nustate, kad karininkų švietimo politikos plètra yra cikliška ir gali būti apibūdinama keturiais švietimo politikos veiksniais: kylančiomis grèsmėmis, besikeičiančia saugumo aplinka, kintančia saugumo ir gynybos politika ir kintančiais reikalavimais karinėms pajègoms. Atsižvelgiant ị kintančius reikalavimus karinėms pajègoms turi būti keičiamas karininkų švietimas ir rengimas. Profesinis rengimas yra sudètingas procesas, apimantis praktinį mokymą, susijusị su profesiniais ịgūdžiais, kompetencijomis, kurị dažnai organizuoja kompetentingi puskarininkiai ir karininkai, o švietimas - intelektinis mokymas, kurio pagrindinis uždavinys - formuoti kompetenciją spręsti, kaip ir kada profesinius igūdžius ir gebejjimus taikyti praktiškai sudètingoje taktinejje, operacinejje ar net strateginejje aplinkoje (Melnikovas, 2019).

Karininkų švietimas ir rengimas, profesinių kompetencijų tobulinimas Lietuvoje yra teisiškai reglamentuotas valstybès, deleguojant mokymo, studijų valdymo ir kontrolès funkcijas Generolo Jono Žemaičio Lietuvos karo akademijai. Lietuvos bazinio karininkų švietimo ir rengimo organizavimas reglamentuotas ịstatymų, detalizuotas statutuose, doktrinose ir įsakymuose (Generolo Jono Žemaičio Lietuvos karo akademijos statutas, 1999, 2020 m. suvestinè redakcija; Lietuvos Respublikos krašto apsaugos sistemos organizavimo ir karo tarnybos ịstatymas, 1998, $2021 \mathrm{~m}$. suvestinè redakcija; Lietuvos karinių pajėgų rengimo doktrina, 2013). Lietuvos Respublikos krašto apsaugos sistemos organizavimo ir karo tarnybos ịstatymo (1998, $2021 \mathrm{~m}$. suvestinè redakcija) nustatyta, kad kariūnai rengiami pagal universitetinių 
studijų, karinio rengimo ir neformaliojo švietimo programas. Generolo Jono Žemaičio Lietuvos karo akademija (LKA) yra patvirtinusi 2018-2024 m. strategiją iškeltiems tikslams pasiekti (LKA, 2018).

Temos aktualumą rodo įvairių šalių mokslininkų darbai apie 4-osios pramonės revoliucijos poveikị darbuotojų kvalifikacijai (Avis, 2018; Kurt, 2019; Pfeiffer, 2015), jos įtaką karybai ir karininkų kvalifikacijos kaitai (Clark, B; Patt, D.; Schramm, 2020; Gell et al., 2018; Holth \& Boe, 2017; Meese \& Calkins, 2006; Orsi, 2017; Park, 2010; Paul Price \& Smith, 2004) bei istorinị karininkų rengimo kontekstą, kvalifikacijos kèlimo Lietuvoje raidą (Gražytè-Miliukienè \& Prakapienè, 2012; Puzinavičius, 2006; Žigaras, 2018, 2019). Veiklos procesų skaitmenizacija ir 4-oji pramonès revoliucija keičia karybos veiklos turinị ir reikalavimus kompetencijoms, šiuo atveju karyba niekuo nesiskiria nuo kitu veiklos sričių, tačiau dėl pažangiųjų pramonės technologijų skvarbos kyla poreikis kariams, ypač karininkams, igyti naujų kompetencijų, bet, kad galima būtų taikyti naująsias kompetencijas karyboje, reikia rasti specifinių prieigu ir būdų, kuriuos lemia šiuo metu naudojami instituciniai karininkų švietimo ir rengimo modeliai. Lietuvos ir užsienio mokslininkų darbų, kuriuose būtų nagrinèjama karininkų kvalifikacijos kaita 4-osios pramonės revoliucijos plètros sąlygomis, nèra arba nepavyko rasti.

Šis tyrimas apima ateities kariavimo pokyčių numatymą remiantis 4-osios pramonès revoliucijos metu besivystančiomis technologijomis, jų perkèlimo ị karybą ypatumais ir įtaka karininkų švietimo ir rengimo politikos pokyčiams, atsižvelgiant i grèsmes nacionaliniam saugumui ir atsirandančias galimybes. Kaip teigia Caselli (1999), technologija yra tam tikro tipo mašinų (irenginių) ir darbuotojų, kurie turi reikalingų igūdžių joms valdyti, kombinacija. Technologinių revoliucijų esmè - naujų mašinų (ịrenginių) naudojimas. Naujo tipo įrenginiai yra daug produktyvesni nei buvę, bet juos valdyti, prižiūrèti gali tik nauji darbuotojai, kurie turi tam reikalingu specifinių ịgūdžių, kompetencijų. Tokių igūdžių, kompetencijų, igyti brangu ir ilgai trunka, todèl kyla klausimas: kam gaišti laiką, jei jau dabar galima ruoštis ateičiai?

Problema - informacijos apie karininkų kompetencijų poreikius, susijusius su karybos procesų skaitmenizacija ir kitomis 4-osios pramonès revoliucijos plètros tendencijomis, stoka.

Tyrimo tikslas - atskleisti būtinus bazinio karininkų rengimo kvalifikacijos struktūros ir turinio pokyčius, kylančius dẻl veiklos procesų skaitmenizacijos ir kitų 4-osios pramonès revoliucijos plètros aspektų.

Tyrimo objektas - karininkų kvalifikacijos struktūros ir turinio kaita 4-osios pramonès revoliucijos plètros sąlygomis.

Tyrimo uždaviniai: apžvelgti karininkų rengimo kvalifikacijos kaitos priežastis; išnagrinèti 4-osios pramonès revoliucijos sampratą; ištirti karių nuomonę apie esamą ir būtiną karininkų kvalifikacijos kaitą atliepiant 4-osios pramonès revoliucijos tendencijas.

Tyrimo metodai: mokslinès literatūros analizè, interviu, turinio analizè, teisinių dokumentų apžvalga. 


\section{Karininkų švietimo ir rengimo kaitos priežastys}

Karininkų profesinis rengimas Europoje prasidèjo XIX a. ir vèliau buvo tęsiamas po Antrojo pasaulinio karo. Tikslas - suteikti jiems atitinkamų teorinių žinių ir praktinių igūdžių (Foot, 2001). Teorinès, akademinès, žinios teikiamos organizuojant švietimą, praktiniai ịgūdžiai - vykdant profesinị rengimą. Nagrinèjant karininkų kvalifikacijų turinị būtina suprasti, kokiomis aplinkybėmis vyksta karininkų rengimo pokyčiai. Kaip teigia Melnikovas (2019), karininkų švietimo politikos plètros modelị formuoja ịvairūs veiksniai: kylančios konvencinès ir nekonvencinès grèsmès (1) daro tiesioginę ịtaką saugumo aplinkai (2), prognozuojant tolesnius saugumo aplinkos pokyčius formuojama naujoji saugumo ir gynybos politika (3), esant poreikiui, gali kisti reikalavimai karinėms pajėgoms (4), tad, siekiant patenkinti naujus reikalavimus karinèms pajègoms, kuriamas naujas karininkų švietimo ir rengimo modelis. Pats procesas yra cikliškas ir gali būti inicijuojamas pagal poreikị (žr. 1 pav.).

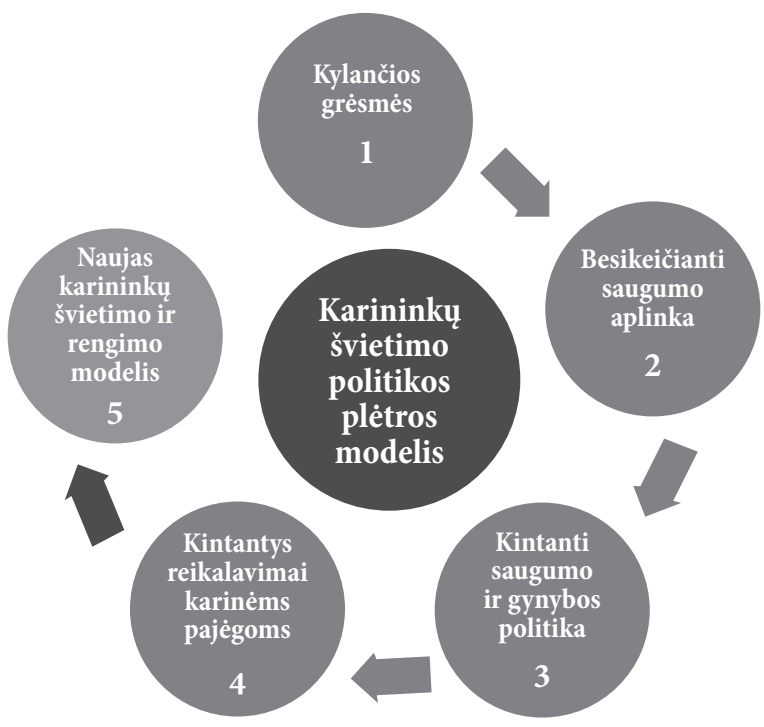

1 pav. Karininkų švietimo politikos plètros modelis (Melnikovas, 2019, p. 89).

Naudodamas ši karininkų švietimo politikos plètros modelį, Melnikovas (2019) apibūdino (Foot, 2001; Libel, 2016) keturis pateiktus modelius: „Jenos“, „Folklando“, „Kosovo“ ir „Nacionalinio gynybos universiteto“ - ir įvardijo pokyčius, atsiradusius kiekviename karininkų švietimo politikos plètros modelio igyvendinimo etape (žr. 1 lentelę). Karininkų kvalifikacijos kaitą lemia naujas švietimo ir rengimo modelis, suformuotas apibrěžus reikalavimus ginkluotosioms pajègoms. Atsiradę nauji reikalavimai turètų inicijuoti kvalifikacijų rinkinio peržiūrą ir kaitą, kad ugdymo įstaigos imtųsi atnaujinti karininkų rengimą. Remiantis Melnikovo (2019) atlikta analize, išskiriamos šios „Jenos“ modelio strateginès gairès naujam švietimo ir rengimo turiniui kurti: greita mobilizacija, karininkų profesionalumas ir 
aukštas pasirengimo lygis. Pagal „Folklando“ modelį, karininkai turi gebėti veikti ne vien nacionaliniame kontekste, bet ir globalioje aplinkoje ir turèti žinių apie visuotinį saugumą, pagal „Kosovo“ modeli - gebèti vykdyti taikos palaikymo operacijas prieštaringoje teisineje, politineje ir socialinejje aplinkoje, konceptualizuoti ir atlikti politinę analizę, turèti sprendimo prièmimo kompetencijų. Galiausiai, pagal „Nacionalinio gynybos universiteto“ modelį, karininkai turi gebèti vykdyti sudètingas bendras operacijas tarptautinio kontingento sudètyje.

1 lentelè. Karininkų švietimo politikos plètros modelio detalizavimas

\begin{tabular}{|c|c|c|c|c|}
\hline Modeliai & $\begin{array}{l}\text { Kylančios } \\
\text { grèsmès }\end{array}$ & $\begin{array}{c}\text { Besikeičianti } \\
\text { saugumo aplinka }\end{array}$ & $\begin{array}{c}\text { Kintanti } \\
\text { saugumo ir } \\
\text { gynybos politika }\end{array}$ & $\begin{array}{c}\text { Kintantys } \\
\text { reikalavimai } \\
\text { karinėms pajėgoms }\end{array}$ \\
\hline Jenos & $\begin{array}{c}\text { Imperialistinès } \\
\text { Prancūzijos } \\
\text { ambicijos }\end{array}$ & $\begin{array}{l}\text { Karinis konfliktas } \\
\text { tarp Prancūzijos } \\
\text { ir Prūsijos }\end{array}$ & $\begin{array}{l}\text { Nuo reguliariosios } \\
\text { profesionalios } \\
\text { kariuomenės iki } \\
\text { visuotinės karo } \\
\text { tarnybos }\end{array}$ & $\begin{array}{c}\text { Greita mobilizacija, } \\
\text { karininkų } \\
\text { profesionalumas ir } \\
\text { aukštas pasirengimo lygis }\end{array}$ \\
\hline Folklando & $\begin{array}{c}\text { Grèsmès } \\
\text { Vakarų šalių } \\
\text { interesams } \\
\text { globalioje } \\
\text { aplinkoje ir/ar } \\
\text { nacionaliniams } \\
\text { interesams už } \\
\text { valstybės ribų }\end{array}$ & $\begin{array}{l}\text { Karinis konfliktas } \\
\text { Folklando salose, } \\
\text { Irano ir Irako karas }\end{array}$ & $\begin{array}{c}\text { Nacionalinio } \\
\text { saugumo } \\
\text { koncepcija } \\
\text { neatsiejama } \\
\text { nuo pasaulinio } \\
\text { saugumo } \\
\text { koncepcijos }\end{array}$ & $\begin{array}{l}\text { Kariuomenè turi gebėti } \\
\text { veikti ne nacionaliniame } \\
\text { kontekste, t. y. } \\
\text { pasaulinėje aplinkoje, } \\
\text { karininkai turi turèti žinių } \\
\text { apie pasaulio saugumą }\end{array}$ \\
\hline Kosovo & $\begin{array}{c}\text { Iššūkiai } \\
\text { nacionaliniams } \\
\text { interesams už } \\
\text { valstybės ribų }\end{array}$ & $\begin{array}{l}\text { Karinis } \\
\text { konfliktas } \\
\text { Kosove }\end{array}$ & $\begin{array}{c}\text { Valstybės } \\
\text { saugumo } \\
\text { koncepcija apima } \\
\text { ne tik nacionalini, } \\
\text { bet ir tarptautini } \\
\text { kontekstą }\end{array}$ & $\begin{array}{l}\text { Kariuomenè turi gebėti } \\
\text { vykdyti taikos palaikymo } \\
\text { operacijas prieštaringoje } \\
\text { teisinejje, politinėje ir } \\
\text { socialinèje aplinkoje; } \\
\text { karininkai turi turèti } \\
\text { konceptualizavimo, } \\
\text { politinės analizės ir } \\
\text { sprendimų prièmimo } \\
\text { kompetencijų }\end{array}$ \\
\hline $\begin{array}{l}\text { Nacionalinio } \\
\text { gynybos } \\
\text { universiteto }\end{array}$ & $\begin{array}{l}\text { Tarptautinis } \\
\text { terorizmas, } \\
\text { etniniai karai } \\
\text { ir kariuomenių } \\
\text { nuosmukis }\end{array}$ & $\begin{array}{l}\text { Teroristiniai } \\
\text { išpuoliai ES šalyse } \\
\text { ir mažèjantis } \\
\text { finansavimas, } \\
\text { skiriamas gynybai } \\
\text { ir saugumui }\end{array}$ & $\begin{array}{c}\text { Nacionalizavo } \\
\text { Europos gynybą } \\
\text { ir saugumą, kad } \\
\text { kompensuotų } \\
\text { sumažejjusį } \\
\text { ginkluotujų pajėgu } \\
\text { finansavimą }\end{array}$ & $\begin{array}{l}\text { Kariuomenè turi } \\
\text { turèti galimybę atlikti } \\
\text { sudètingas bendras } \\
\text { operacijas tarptautinio } \\
\text { kontingento sudètyje }\end{array}$ \\
\hline
\end{tabular}

Sudaryta autoriaus remiantis: Melnikovas (2019)

Lietuvos nacionalinę gynybos strategiją ir politiką apibrèžia karinès doktrinos. Lietuvos karinių pajėgų operacinè doktrina reglamentuoja, „kaip veikti“, Lietuvos kariuomenès rengimo doktrina - „kaip rengti“ (2013). Melnikovas (2019) 
teigia, kad karininkų rengimo modelio prièmimas siejamas su strateginio lygmens pokyčiais, kas ne prieštarauja Lietuvos kariuomenès rengimo doktrinai, o ją remia. Tačiau Melnikovas patikslina, kad reikalavimai karinėms pajègoms (žr. 1 pav.) yra strateginio - politinio lygmens. Prieštaravimų kelia pokyčių inicijavimas grèsmès akivaizdoje arba ,išmoktų pamokų“ pagrindu.

Karininkų rengimo politika pirmiausia igyvendinama keičiant doktrinas ir kitus nacionalinius dokumentus (Kenney, 1996). Tačiau nacionalinę opiniją gali lemti ir dažnai lemia platesnis kontekstas, o ịtaka karininkų rengimo turiniui gali būti daroma nebūtinai laikantis principo „,ǐ̌ viršaus ị apačią“. „Mokslininkai teigia, jog karybos pokyčiai vyksta trimis būdais: adaptacija (angl. adaptation), inovacija (angl. innovation) ir pamėgdžiojimu (angl. emulation)“(Šlekys, 2015, p. 14). Nors Šlekys nebūtinai kalba apie su švietimu ir rengimu susijusius karybos pokyčius, tačiau atkreiptinas dėmesys, kad bent jau lietuviai daugeli idèjų iš užsienio tiesiog „pasiskolina“ ir jų neadaptuoja (veikiama copy - paste principu), tad darytina prielaida, kad tam tikros naujos karininkų švietimo ir rengimo idejos, struktūra ir turinys gali būti diegiami būtent tokiu būdu, kai karinè ir politinè vadovybė nesiekia kritiškai vertinti siūlomų naujovių, o šios diegiamos iš esmès kokybiškai nekeičiant esamo karininkų švietimo ir rengimo modelio.

Keagle ir Petros (2010) pateike žmogiškojo kapitalo vystymo gaires NATO ir programoje „Partnerystė taikos labui“ (angl. Patnership for Peace) dalyvaujančioms šalims, pabrèždami, kad NATO reikalingi saugumo srities profesionalai, gebantys mąstyti strategiškai (ne tik taktiniu ir operaciniu lygmeniu), kritiškai ir kūrybiškai, vadovauti tarpžinybinėms grupėms, bendradarbiauti ir ịtikinti, ne tik duoti ịsakymus (komanduoti), planuoti ir valdyti tarpžinybines operacijas. Jie turi pasižymèti globaliu ir kultūriniu jautrumu, tinkamai bendrauti (komunikuoti), o ne tik ịsakinèti. Pati orientacija ị saugumo ekspertų rengimą, atsisakant karinès srities profesionalų ar karininkų rengimo akcentavimo, suponuoja karinès profesijos paradigmos pokytị, kaip tai apibūdino Libel (2016). Galima teigti, kad NATO gynybinis aljansas ar jo dalis kryptingai juda link „Nacionalinio gynybos universiteto“ karininkų švietimo ir rengimo modelio taikymo. Pagrindus šią prielaidą, daug lengviau pasirinkti naują pamatinị karininkų rengimo modelị, leidžiantị lanksčiai konstruoti karininkų kvalifikacijas, atsižvelgiant ị dabartinius socialinius, ekonominius ir technologinius pokyčius.

Visi Europos Sajungos gynybos ministrai 2008 m. pasirašè susitarimą plètoti Europos mokymo ịstaigų jaunesniujų karininkų mainus. Ši iniciatyva sukurta pagal „Erasmus“ programą, ją igyvendindamos valstybès koordinuoja karininkų švietimą, kuria bendrus modulius, jungtines magistrantūros studijas (Gell et al., 2018). Tokios iniciatyvos gerina švietimo ir rengimo kokybę, tačiau reikalauja papildomo derinimo. Kuriant naujus karininkų švietimo ir rengimo modelius, keičiant struktūrą ir turinį, būtina atsižvelgti ị NATO ir Europos Sajungos karininkų švietimo, profesinio rengimo iniciatyvas ir programas.

Apibendrinant galima teigti, kad pagrindinè karininkų švietimo ir rengimo kaitos priežastis yra istorinis aspektas (išmoktos pamokos), todèl laiku inicijuoti 
karinio personalo švietimo, kvalifikacijos struktūros ir turinio politikos pokyčiai gali svariai prisidèti užtikrinant kariuomenès pasirengimą tinkamai ir veiksmingai reaguoti $\mathfrak{i}$ tradicines ir netradicines grèsmes. Kvalifikacijos pokyčiai turètų ne tik būti orientuoti i i išmoktas pamokas, bet ir padèti numatyti kylančias grèsmes ar atsirandančias galimybes. Taip pat labai svarbus kvalifikacijos turinio suderinamumas su NATO ir Europos Sajungos partneriais.

\section{Sąvokos „ketvirtoji pramonės revoliucija“" samprata}

Pirmoji pramonès revoliucija, arba procesai „Pramonè 1.0“ (literatūroje šie terminai vartojami kaip sinonimai - aut. pastaba), prasidejo XIX a. pirmoje pusejje, o jos pagrindas buvo garo variklio naudojimas gamybos ir transporto srityje (žr. 1 lentelę). Ši revoliucija pakeite žmonių gyvenimą ir ekonomiką iš agrarinès ir rankdarbių ekonomikos ị tokią, kurioje vyravo pramonè ir mašinų gamyba. Anglis tapo pagrindiniu kuru, o garvežiai - pagrindine transporto priemone ir progreso priežastimi (Xu \& Kim, 2018, p. 90).

Antroji pramonès revoliucija prasidejo XIX a. viduryje, išradus vidaus degimo varikli. Nafta ir elektros energija tapo naujais energijos šaltiniais.

Trečioji pramonès revoliucija prasidèjo $1960 \mathrm{~m}$., elektronika ir informacinès technologijos igalino automatizuoti gamybą pasitelkiant robotus. Padidèjusią energijos paklausą patenkino branduolinè ir gamtinių dujų energetika (P. Prisecaru, 2016; M. Xu et al., 2018).

2 lentelè. Pramonès revoliucijos

\begin{tabular}{|c|c|c|c|c|}
\hline & $\begin{array}{c}\text { 1-oji pramonès } \\
\text { revoliucija }\end{array}$ & $\begin{array}{c}\text { 2-oji pramonės } \\
\text { revoliucija }\end{array}$ & $\begin{array}{c}\text { 3-ioji pramonės } \\
\text { revoliucija }\end{array}$ & $\begin{array}{c}\text { 4-oji pramonès } \\
\text { revoliucija }\end{array}$ \\
\hline Laikotarpis & $1760-1900 \mathrm{~m}$. & $1900-1960 \mathrm{~m}$. & $1960-2000 \mathrm{~m}$. & Nuo $2000 \mathrm{~m}$. \\
\hline $\begin{array}{c}\text { Energijos } \\
\text { šltinis }\end{array}$ & Anglis & Nafta, elektra & $\begin{array}{c}\text { Branduolinè } \\
\text { energija, dujos }\end{array}$ & Žalioji energetika \\
\hline $\begin{array}{c}\text { Pagrindinis } \\
\text { proveržis }\end{array}$ & $\begin{array}{c}\text { Mechanizacija, } \\
\text { garo variklis }\end{array}$ & $\begin{array}{c}\text { Vidaus degimo } \\
\text { variklis }\end{array}$ & $\begin{array}{c}\text { Kompiuteriai, } \\
\text { robotai }\end{array}$ & $\begin{array}{c}\text { Kibernetinès } \\
\text { fizinès sistemos }\end{array}$ \\
\hline
\end{tabular}

Šaltinis: sudaryta autoriaus remiantis: Prisecaru (2016), Avis (2018), M. Xu et al. (2018).

Daugelis mokslininkų, tyrinejjančių 4-osios pramonès revoliucijos ypatumus, susiduria su sutarto apibrèžimo trūkumu. Šis trūkumas kelia rimtų apribojimų kuriant teorijas ir lyginant tyrimus. Nuo pradinio vokiečių pasiūlyto 4-osios pramonès revoliucijos sąvokos konceptualizavimo $2011 \mathrm{~m}$. šio termino turinys labai pasikeite, todèl atsirado neaiškumų. Lygiagrečiai panašios sąvokos, dažnai vartojamos kaip sinonimai, pvz., „sumanioji gamyba“, „skaitmeninè transformacija“ ir „,ketvirtoji pramonès revoliucija“, sukèlè painiavą dèl šio reiškinio apimties ir ypatybių. 4-oji pramonès revoliucija prasidejo, tačiau ji nuolatos kinta ir transformuojasi, tad galutinai lieka neaišku, kokias sritis ji apims ir kada bei kaip prasidès 5-oji pramonès 
revoliucija. Galima teigti, kad 4-osios pramonès revoliucijos pagrindinis tikslas gamybos procesų efektyvumas, konkurencingumas, išmanumas, ir to siekiama sujungiant fizinị ir skaitmeninị pasaulius ị visumą, ịprastai naudojant internetą (Liao et al., 2017; Vaidya et al., 2018; L. da Xu et al., 2018).

3 lentelè. Ketvirtosios pramonės revoliucijos samprata

\begin{tabular}{|c|c|}
\hline Šaltiniai & Ketvirtosios pramonès revoliucijos samprata \\
\hline $\begin{array}{l}\text { Vaidya et al., } \\
2018, \text { p. } 234\end{array}$ & $\begin{array}{l}\text { „Ketvirtosios pramonės revoliucijos paradigma skatina fizinių elementų, } \\
\text { tokių kaip jutikliai, ịrenginiai ir ịmonès turtas, jungimą tarpusavyje ir prie } \\
\text { interneto, }<\ldots>\text { šios pramonès poreikis yra ịprastas mašinas paversti savaime } \\
\text { suprantančiomis ir besimokančiomis mašinomis, kad pagerètų jų bendras našumas } \\
\text { ir priežiūros valdymas }<\ldots \text {.. > }\end{array}$ \\
\hline $\begin{array}{l}\text { L. da } \mathrm{Xu} \\
\text { et al., } 2018 \text {, } \\
\text { p. } 2942-2943\end{array}$ & $\begin{array}{l}\text { „Ketvirtoji pramonės revoliucija labai pakels bendrą industrializacijos, } \\
\text { informacinių technologijų ir gamybos skaitmeninimo lygị, kad būtų pasiektas } \\
\text { didesnis efektyvumas, kompetencija ir konkurencingumas.“ }\end{array}$ \\
\hline $\begin{array}{l}\text { Lasi et al., } \\
2014, \text { p. } 240\end{array}$ & $\begin{array}{l}\text { „Ketvirtoji pramonès revoliucija apibūdina skirtingus gamybos sistemų pokyčius, } \\
\text { visų pirma IT skatinamus. Šie pokyčiai turi ne tik technologinių, bet ir ịvairiapusių } \\
\text { organizacinių padarinių.“ }\end{array}$ \\
\hline
\end{tabular}

Šaltinis: sudaryta autoriaus remiantis: Vaidya et al. (2018, p. 234), L. da Xu et al. (2018, p. 2942-2943), Lasi et al. (2014, p. 240).

Ketvirtoji pramonės revoliucija suprantama kaip bendrinis pavadinimas - kibernetinès fizinès sistemos (angl. cyberphysical systems - CPSs). Jas sudaro fiziniai objektai (pvz., šviesoforas, automobilis, šaldytuvas, robotas), duomenų modelis (sąsajos), esantis tinklo infrastuktūroje, skirtas išvardintiems fiziniams objektams, bei paslaugos (angl. services), operuojančios surinktais (turimais) duomenimis. Kibernetinès fizinès sistemos jungiamos tarpusavyje, todèl jungiamujų dalių ir (ar) duomenų modelių (sąsajų) bei paslaugų yra labai daug. Fiziniai objektai, kad ir kokie jie būtų, pvz., autonominiai robotai, suvirinimo įrenginys ir t. t., ar kiti internetu sąveikaujantys įrenginiai (angl. Internet of Things, IoT) ir pramoniniai internetu sąveikaujantys įrenginiai (angl. Industrial Internet of Things, IIoT) turi mažus, galingus jutiklius (Prisecaru, 2016), kurie renka, apdoroja ir siunčia duomenis. Daiktai generuoja didžiulius kiekius informacijos, taip atsiranda didieji duomenys, jų analitika, pasitelkiamas mašininis mokymasis (machine learning) ir (ar) dirbtinis intelektas. Duomenų apdorojimui bei sprendimų prièmimui, efektyviam paslaugų teikimui naudojamasi debesijos paslaugomis (Vaidya et al., 2018; L. da Xu et al., 2018). Fiziniu daiktų jungimas ị tinklą, didelių duomenų atsiradimas suponuoja išaugusị kibernetinị pažeidžiamumą, kuriam turi būti skiriamas didesnis dèmesys. Dar sunkiau apibrežti 4-osios pramonès revoliucijos požymius, kai bandoma susisteminti pažangos darbus biologijos srityje. Didžiausias proveržis laukiamas genų inžinerijoje (genu redagavimas (CRISPR/Cas9)), pažangiojoje medicinoje (ligų diagnozavimas ir gydymas, gyvujų audinių spausdinimas (angl. living tissues), bet svarbiausia yra visų technologijų sintezè (angl. technology fusion) (Liao et al., 2017; Schwab, 2016). 
4 lentelè. Ketvirtosios pramonès revoliucijos požymiai

\begin{tabular}{|c|c|}
\hline Šaltiniai & Ketvirtosios pramonės revoliucijos požymiai \\
\hline $\begin{array}{l}\text { Vaidya et al., } \\
2018, \text { p. } 234\end{array}$ & $\begin{array}{l}\text { „Didieji duomenys ir analitika, autonominiai robotai (Autonomous Robots), } \\
\text { modeliavimas, horizontali ir vertikali sistemos integracija, pramoninis daiktų } \\
\text { internetas, kibernetinis saugumas ir fizinės sistemos debesija, priedų gamyba, } \\
\text { papildyta realybė, }<\ldots>\text { 4-osios pramonès revoliucijos paradigma skatina fizinių } \\
\text { elementu, tokių kaip jutikliai, įrenginiai ir ịmonès turtas, jungimą tarpusavyje ir } \\
\text { prie interneto, }<\ldots>\text { šios pramonės poreikis - ịprastas mašinas paversti savaime } \\
\text { suprantančiomis ir besimokančiomis mašinomis, kad pagerètų jų bendras našumas } \\
\text { ir priežiūros valdymas kartu su aplinkiniais, }<\ldots>\text { varomosios jègos yra daiktų } \\
\text { internetas (IoT), pramoninis daiktų internetas (IloT), debesijos duomenimis } \\
\text { grịsta gamyba ir išmanioji gamyba, padedanti gamybos procesą paversti visiškai } \\
\text { skaitmenizuotu ir protingu.“ }\end{array}$ \\
\hline $\begin{array}{l}\text { Prisecaru, } \\
\text { 2016, p. } 57-58\end{array}$ & $\begin{array}{l}\text { „Ketvirtosios pramonės revoliucijos išskirtiniai požymiai yra greitas internetas, } \\
\text { maži, bet galingi jutikliai, dirbtinis intelektas, virtualių ir fizinių sistemų sinteze.“ }\end{array}$ \\
\hline $\begin{array}{l}\text { Monostori } \\
\text { et al., } 2016 \text {, } \\
\text { p. } 621\end{array}$ & $\begin{array}{l}\text { „Kibernetinės fizinės gamybos sistemos (CPPS), pagrįstos naujausiais ir } \\
\text { numatomais tolesniais kompiuterių mokslo (CS), informacinių ir ryšiu technologijų } \\
\text { (IRT) bei gamybos mokslo ir technologijų (MST) pokyčiais, gali sukelti ketvirtają } \\
\text { pramonès revoliuciją <...>“ }\end{array}$ \\
\hline $\begin{array}{c}\text { L. da Xu } \\
\text { et al., } 2018 \text {, } \\
\text { p. } 2941-2942\end{array}$ & $\begin{array}{l}\text { „Ketvirtoji pramonės revoliucija atspindi dabartinę automatizavimo technologijų } \\
\text { tendenciją pramonėje ir daugiausia apima tokias technologijas kaip kibernetinès } \\
\text { fizinės sistemos (CPS), daiktų internetas (IoT) ir debesų kompiuterija.“ }\end{array}$ \\
\hline
\end{tabular}

Šaltinis: sudaryta autoriaus remiantis: Vaidya et al. (2018, p. 234), Prisecaru (2016, p. 57-58),

Monostori et al. (2016, p. 621), L. da Xu et al. (2018, p. 2941-2942).

Atsirandančios naujos technologijos keičia konfliktų pobūdị ir kariavimo būdus. Jau dabar kartais sunku atskirti karą nuo taikos, kariuomenès, igyvendindamos politikų valią (Carl von Clausewitz, 1989), naudoja smurtą neskelbdamos karo, neidentifikuodamos savęs (Teper, 2016). Moderniuose konfliktuose susipynę įvairūs metodai ir priemonès, kurie būdavo naudojami ne valstybių, o ịprastai teroristiniu organizacijų. Kaip teigia Schwab (2016), technologijoms susiliejant vis labiau ir nenuspejjamais būdais, valstybiniams ir ginkluotiems nevalstybiniams subjektams mokantis vieniems iš kitų, galimas pokyčių mastas dar nèra plačiai įvertintas. Vykstant šiam procesui tampa lengviau įsigyti ir naudoti naujas mirtinas technologijas, akivaizdu, kad ketvirtoji pramonès revoliucija siūlo vis įvairesnius būdus, leidžiančius pakenkti aplinkiniams didžiuliu mastu. Tai suvokus, atsiranda didesnis pažeidžiamumo jausmas, tačiau galimybė naudotis technologijomis taip pat suteikia didžiules perspektyvas.

Apibendrinant galima teigti, kad pramonès revoliucijų metu vystosi ịvairios technologijos, kurios leidžia efektyviau, našiau atlikti darbą. Karyba - ne išimtis. Ketvirtosios pramonès revoliucijos sąvoka turi aibę sinonimų, o svarbiausia, kad šios pramonès požymiai nėra nusistovèję, nuolatos kinta, bet atliekant literatūros analizę buvo nustatyti trys pagrindiniai agreguoti požymiai: fiziniai objektai, duomenų modelis ir paslaugos. 


\section{Tyrimo metodologija}

Siekiant išanalizuoti karių (tarnaujančių ar atsargos karininkų), rengiančių būsimus karininkus, požiūrị ị karininkų kvalifikacijos kaitą, buvo atliktas empirinis tyrimas. Tyrimui pasirinkta Generolo Jono Žemaičio Lietuvos karo akademija, nes tai - pagrindinè institucija Lietuvoje, kuri yra atsakinga už karininkų rengimą (Krašto apsaugos sistemos organizavimo ir karo tarnybos įstatymas, 1998, $2020 \mathrm{~m}$. suvestinè redakcija).

„Karo akademijos misija - Lietuvos karo akademija yra išskirtinis Lietuvos universitetas, kuriame harmoningai derinamos universitetinès studijos ir karinis rengimas, kokybiškai rengiami ir ugdomi visapusiškai išsilavinę ir atsakingi karininkai lyderiai, vykdomi moksliniai tyrimai bei užtikrinimas mokymosi visą gyvenimą principų igyvendinimas pagal KAS poreikius" (LKA, 2018).

Empirinio tyrimo tikslas - ištirti karių, atsargos karių, tarnaujančių (dirbančių) LKA, nuomonę apie esamą ir reikalingą būsimą bazinio karininkų rengimo kvalifikacijos struktūros ir turinio kaitą 4-osios pramonès revoliucijos sąlygomis.

Tyrimo metodai - interviu, turinio analizè.

Tyrimas buvo atliekamas Bryman (2008) išskirtais etapais: 1) remiantis išanalizuota teorine medžiaga ir tyrimo tikslu, uždaviniais, sudarytas interviu klausimynas; 2) atlikta informantų atranka, atsižvelgiant ị iškeltus tyrimo dalyvių atrankos kriterijus; 3) atlikti interviu; 4) padaryta interviu transkripcija ir gautų tyrimo duomenų turinio analizé; 5) suformuluotos tyrimo išvados.

Tyrimo instrumentas. Interviu klausimynas buvo parengtas remiantis atlikta teorine pasirinktos temos analize (Foot (2001), Melnikovas (2019), Libel (2016, 2019), Šlekys (2015), Schwab (2016). Informantai iš anksto klausimyno negavo, interviu metu jiems buvo užduodami parengti atviri klausimai, vẻliau atsakymai buvo tikslinami užduodant papildomus atvirus ir uždarus klausimus. Interviu klausimai buvo sudaryti siekiant išsiaiškinti veiksnius, lemiančius karininkų rengimo programų pokyčius, technologines naujoves, jau taikomas LK pastaruosius dešimt metų, taip pat ịvertinti, ar respondentai ịžvelgia ateinančias techologines naujoves, kurios, tikimasi, bus taikomos LK. Galiausiai respondentų buvo klausiama apie būtinus karininkų švietimo ir rengimo pokyčius atliepiant technologinę pažangą.

Informantu atranka. Informantų atranka vykdyta formuluojant atrankos kriterijus (žr. 5 lentelę) taip, kad jie atspindètų tyrimo problemos turinị. Informantai atrinkti atsižvelgiant ị kelis kriterijus: tarnybos vietą (personalas, kuris tiesiogiai rengia karininkus ir (ar) prisideda prie programų sudarymo), tarnybos stažą (8 metai ar didesnis karo tarnybos stažas), statusą (karinis personalas arba išejęs ị atsargą personalas), asmenine patirtị rengiant mokymo programas ir vykdant rengima, išsilavinima (aukštasis) ir tarnybos laiką. Tyrimo imtis -6 informantai. Pradiniai informantai pasirinkti taikant patogiają dalyvių atranką, nes personalas buvo labai užsièmęs, ir tik jau vykstant tyrimui pritaikyta atranka sniego gniūžtės principu. 
Tyrèjas prašè tyrimo dalyvių rekomenduoti kitus asmenis, kurie galètų susidomèti atliekamu tyrimu ir galbūt sutiktų dalyvauti interviu (Žydžiūnaitė \& Sabaliauskas, 2017). Informantų, dalyvavusių tyrime, skaičių nulėmė duomenų prisotinimo efektas, „kokybiniam tyrimui neaktualus tiriamujų skaičius, o aktualus gauto interviu teksto turinys - jo gilumas, išsamumas, nauja informacija“ (Žydžiūnaite, 2011, p. 78).

5 lentelè. Informantų atrankos kriterijai

\begin{tabular}{|c|c|c|c|c|c|}
\hline Informantai & $\begin{array}{c}\text { Tarnybos/ } \\
\text { darbo } \\
\text { vieta }\end{array}$ & Statusas & $\begin{array}{c}\text { Asmeninė patirtis } \\
\text { rengiant mokymo } \\
\text { programas/vykdant } \\
\text { rengimą }\end{array}$ & Išsilavinimas & $\begin{array}{c}\text { Tarnybos } \\
\text { laikas }\end{array}$ \\
\hline Informantas nr. 1 & LKA & $\begin{array}{c}\text { Rezervo } \\
\text { karininkas }\end{array}$ & $-/+$ & Bakalauras & $\begin{array}{c}\text { Mažiau nei } \\
15 \text { metų }\end{array}$ \\
\hline Informantas nr. 2 & LKA & Karininkas & $+/+$ & Bakalauras & $\begin{array}{c}\text { Daugiau nei } \\
20 \text { metu }\end{array}$ \\
\hline Informantas nr. 3 & LKA & Karininkas & $+/+$ & Magistras & $\begin{array}{c}\text { Daugiau nei } \\
20 \text { metu }\end{array}$ \\
\hline Informantas nr. 4 & LKA & Karininkas & $+/+$ & Magistras & $\begin{array}{c}\text { Daugiau nei } \\
20 \text { metų }\end{array}$ \\
\hline Informantas nr. 5 & LKA & Karininkas & $+/+$ & Magistras & $\begin{array}{c}\text { Daugiau nei } \\
20 \text { metų }\end{array}$ \\
\hline Informantas nr. 6 & LKA & $\begin{array}{c}\text { Atsargos } \\
\text { karininkas }\end{array}$ & $-/+$ & $\begin{array}{c}\text { Daugiau nei } \\
20 \text { metų }\end{array}$ \\
\hline
\end{tabular}

Šaltinis: sudaryta autoriaus.

Tyrimo etika. Atliekant tyrimą buvo pasirūpinta tyrimo dalyviais ir jų gerove. Tyrèjas užtikrino etinių principų laikymąsi, taip pat informantų ir tyrèjo saugumą, pagarbos asmens privatumui ir jo užimtumui, konfidencialumo bei anonimiškumo principų igyvendinimą (Žydžiūnaitė \& Sabaliauskas, 2017). Informantams buvo priskirti kodai, taip pat jie nebuvo informuoti, kas ir kiek tiksliai asmenų dalyvauja tyrime. Visos informantų pateiktos pavardès buvo nuasmenintos. Tyréjas, siekdamas išlaikyti informantų anonimiškumą, jų tarnybos laiką nurodė naudodamas tik dvi parinktis: daugiau kaip 20 metų arba mažiau nei 15 metų. Pasitaręs su informantais (IM1 ir IM6), tyrejjas nusprendè atskleisti jų tikslų statusą (žr. 5 lentelę).

Tyrimas atliktas $2021 \mathrm{~m}$. gegužès-liepos mènesiais.

\section{Tyrimo rezultatai ir jų aptarimas}

Sociodemografinès tiriamujų charakteristikos. Tyrimo dalyviams buvo būdingos šios sociodemografinès charakteristikos: informantų kvalifikacija ir karinè patirtis.

Pagal išsilavinima tyrimo dalyviai pasiskirste taip: visi informantai yra igiję 
aukštajị universitetinị išsilavinimą.

Pagal tarnybos staža: mažiausią karo tarnybos stažą - mažiau nei 15 metų turi tik vienas informantas (IM1), visi kiti - daugiau nei 20 metų. Tyrime dalyvavusių informantų karo tarnybos stažo vidurkis - 18 metų.

Tyrimo dalyviai buvo suinteresuoti tinkamai atsakyti į klausimus, nes visi dirba būsimų karininkų rengimo srityje, todèl ịsitraukè ị tyrimą.

Veiksniai, lemiantys karininkų rengimo programų pokyčius. Tyrimo metu siekta nustatyti bazinio karininkų rengimo kvalifikacijos pokyčio mechanizmus. Kategoriją „Veiksniai, lemiantys karininkų rengimo programų pokyčius“ sudaro šešios subkategorijos (žr. 6 lentelę).

6 lentelè. Veiksniai, lemiantys karininkų rengimo programų pokyčius

\begin{tabular}{|c|c|c|}
\hline Kategorija & Subkategorija & Irodantis teiginys \\
\hline \multirow{5}{*}{$\begin{array}{l}\text { Veiksniai, } \\
\text { lemiantys } \\
\text { karininkų } \\
\text { rengimo } \\
\text { programų } \\
\text { pokyčius }\end{array}$} & $\begin{array}{l}\text { Kinta dèl naujo } \\
\text { viršininko } \\
\text { atèjimo }\end{array}$ & $\begin{array}{l}\text { „<..> naujas viršininkas daro revoliucijas. Keičia pagal save, } \\
\text { kaip jis mato, kokia jo patirtis“ (IN1); „LKA viršininkas inicijavo } \\
\text { programos pakeitimą }<\ldots \text {..>“ (IN4) }\end{array}$ \\
\hline & $\begin{array}{l}\text { Vadovèlių, } \\
\text { doktrinos } \\
\text { kaitos }\end{array}$ & 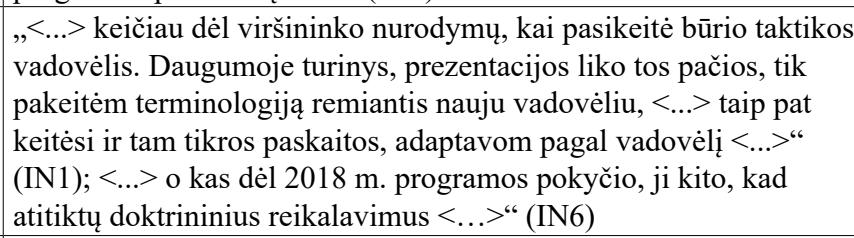 \\
\hline & $\begin{array}{l}\text { Išteklių } \\
\text { apribojimai }\end{array}$ & $\begin{array}{l}\text { „Apribojimai aprūpinimui sąlygoja mažiau praktikos“ (IN1). } \\
\text { „Didèjantis kariūnų skaičius reikalauja daugiau resursų, keičiam, } \\
\text { adaptuojam programas“(IN2) }\end{array}$ \\
\hline & $\begin{array}{l}\text { Naujos } \\
\text { technikos, } \\
\text { ginkluotès } \\
\text { atsiradimas }\end{array}$ & $\begin{array}{l}\text { „<..> pvz., GMG granatsvaidžių atsiradimas keite ginkluotės ir } \\
\text { šaudybos mokymo turinį““ (IN2) }\end{array}$ \\
\hline & $\begin{array}{l}\text { Dèl vidinių } \\
\text { personalo/ } \\
\text { organizacijų } \\
\text { ambicijų, } \\
\text { užgaidų }\end{array}$ & 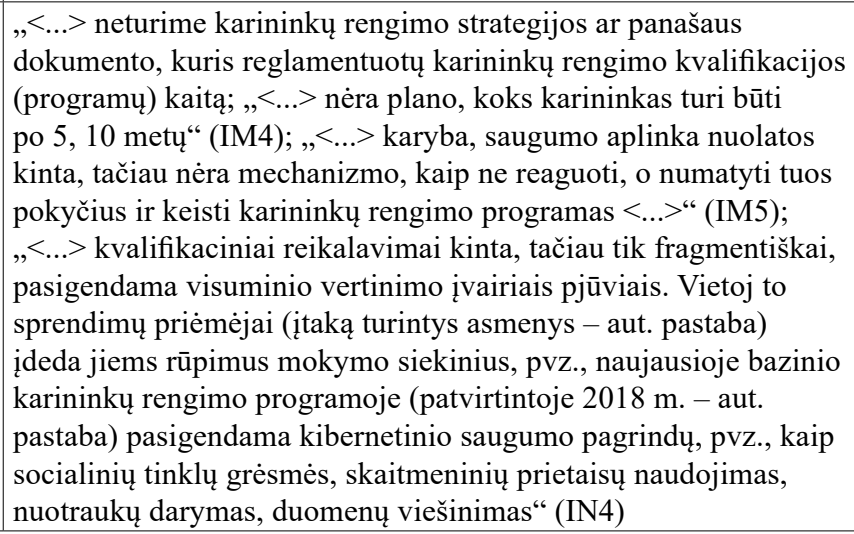 \\
\hline
\end{tabular}




\begin{tabular}{|c|c|c|}
\hline $\begin{array}{l}\text { Veiksniai, } \\
\text { lemiantys } \\
\text { karininkų } \\
\text { rengimo } \\
\text { programų } \\
\text { pokyčius }\end{array}$ & $\begin{array}{c}\text { Mokymo } \\
\text { reikalavimų } \\
\text { specifikacijos } \\
\text { pokytis }\end{array}$ & 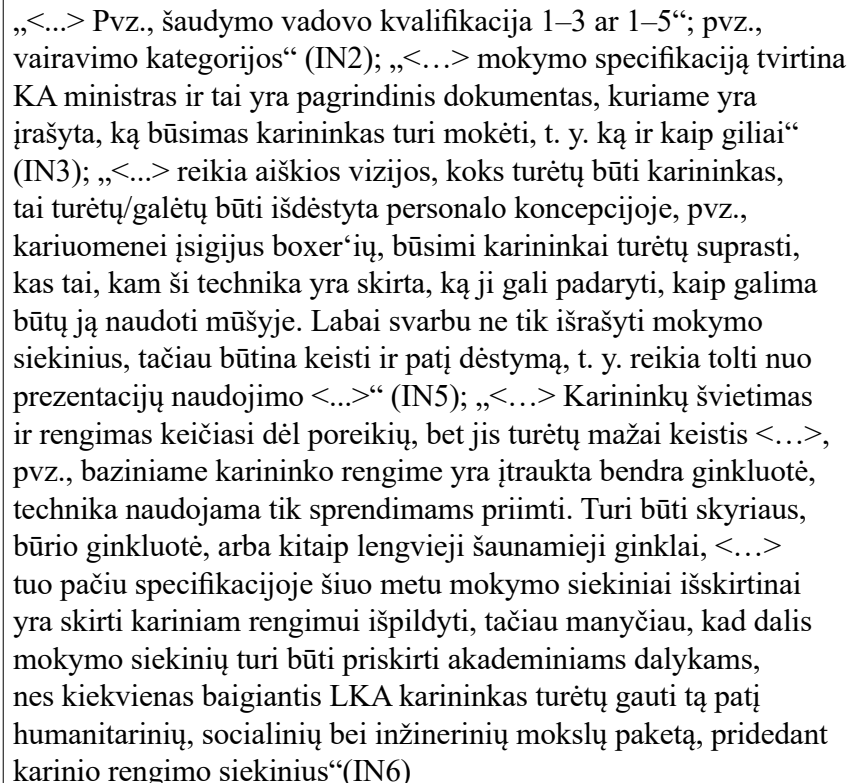 \\
\hline
\end{tabular}

Šaltinis: sudaryta autoriaus.

Apibendrinus tyrimo dalyvių nuomonę apie veiksnius, lemiančius karininkų (bazinio rengimo) programų pokyčius, pastebima, kad informantai išskyre šešis pagrindinius veiksnius (žr. 6 lentelę): jos kinta dèl naujo viršininko atẻjimo, vadovèlių, doktrinos kaitos, išteklių apribojimų, naujos technikos, ginkluotès atsiradimo, dèl vidinių personalo/organizacijų ambicijų, užgaidų ir mokymo reikalavimų specifikacijos pokyčio. Dauguma informantų, t. y. keturi iš šešių, nurodè, kad mokymo reikalavimų specifikacija yra pagrindinis dokumentas, nuo kurio formaliai prasideda pokytis.

Surinktų duomenų analizė leidžia teigti, kad programos struktūra ir turinys nuolatos kinta, įžvelgiami oficialūs ir neoficialūs pokyčiai. Vieni pokyčiai ịtvirtinami keičiant programas, kiti vyksta bandant prisitaikyti prie esamos realios situacijos. Pastebèta, kad tyrimo dalyvių atsakymai priklausè nuo informantų kuruojamų sričiu ir tarnybos (darbo) KAS patirties, pvz., vienam informantui (IN6) rūpejjo, kad programos atitiktų kvalifikacinius reikalavimus, kvalifikacijos struktūra bei turinys, kai kiti nurode tik pavienius aspektus. Visi jie, manytina, yra reakcinio pobūdžio, kai pokyčiai ịgyvendinami keičiantis poreikiams ar aplinkybėms. Atlikus apklausą nebuvo gauta ịrodymų, kad programų pokyčiai būtų nulemti naujųjų technologijų skvarbos. Taip pat informantai atsakymuose neišskyrė pokyčių, kuriuos lemia karybos skaitmenizavimas.

\section{Technologinės naujovès, taikomos karyboje LK per pastaruosius dešimt}

metų. Tyrimo metu siekta nustatyti, su kokiomis technologinėmis naujovėmis yra susidūrę informantai. Kategoriją „Technologinès naujovès, taikomos karyboje LK per pastaruosius dešimt metų“ sudaro penkios subkategorijos (žr. 7 lentelę). Šios subkategorijos atkleide technologinị karybos, kariavimo pokytį. 
7 lentelė. Technologinès naujovès, taikomos karyboje LK per pastaruosius dešimt metu

\begin{tabular}{|c|c|c|}
\hline Kategorija & Subkategorija & Irodantis teiginys \\
\hline \multirow{5}{*}{$\begin{array}{l}\text { Technologinès } \\
\text { naujovès, } \\
\text { taikomos } \\
\text { karyboje LK } \\
\text { per pastaruosius } \\
\text { dešimt metu }\end{array}$} & $\begin{array}{c}\text { Karinio } \\
\text { rengimo } \\
\text { inovacijos }\end{array}$ & $\begin{array}{l}\text { „Kariūnų rengimui taikoma „Miles“ sistema (integruota } \\
\text { lazerinė mūšio sistema }- \text { aut. pastaba)“ (IN1); „, „Miles“" } \\
\text { sistemos naudojimas indivualiam, kolektyviniam karių } \\
\text { rengimui, }<\ldots>\text { tai labai svarbi sistema karių rengimui } \\
\text { mūšio lauke, }<\ldots \text {... labai svarbu, kad karys gali suprasti savo } \\
\text { daromas klaidas“ (IN4); „< ..> Jcats sistema“ (IN6) }\end{array}$ \\
\hline & $\begin{array}{c}\text { Dronų } \\
\text { atsiradimas }\end{array}$ & 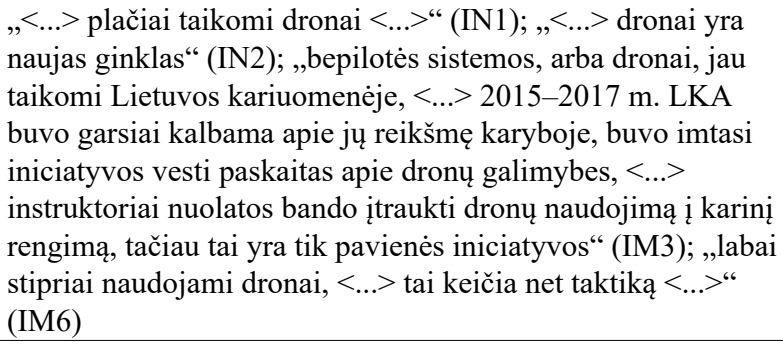 \\
\hline & $\begin{array}{l}\text { Suskaitmenintas } \\
\text { sprendimo } \\
\text { prièmimas, } \\
\text { isakymų } \\
\text { rengimas }\end{array}$ & $\begin{array}{l}\text { „Planavimo procesas bataliono lygmenyje yra } \\
\text { skaitmenizuotas“( IN4); „, „..> naudojamos ịvairios } \\
\text { programèlès, informacija koduojama, pasitelkiamos } \\
\text { „civilinės“ aplikacijos, pvz., „Signal“ ir kt. (kiti pavyzdžiai } \\
\text { sąmoningai neįvardijami - aut. pastaba)“ (IN5) }\end{array}$ \\
\hline & $\begin{array}{l}\text { Naujos } \\
\text { ginkluotės, } \\
\text { ịrangos } \\
\text { atsiradimas }\end{array}$ & 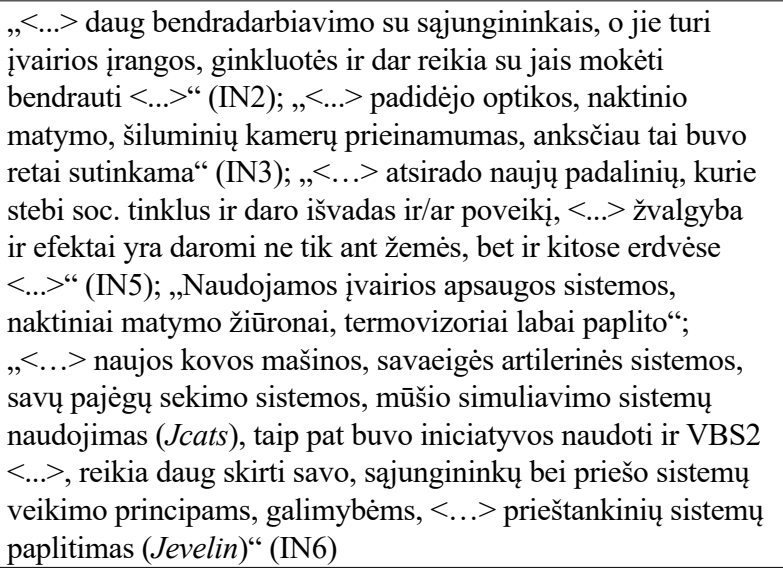 \\
\hline & $\begin{array}{c}\text { Procesų } \\
\text { skaitmenizacija, } \\
\text { automatizavimas }\end{array}$ & „<..> procesų skaitmeninimas, ypač logistinių < ..." (IM6) \\
\hline
\end{tabular}

Šaltinis: sudaryta autoriaus.

Apibendrinant tyrimo dalyvių nuomones apie technologines naujoves, taikomas karyboje pastaruosius dešimt metų, galima teigti, kad visi informantai pateikè technologinių naujovių taikymo Lietuvos kariuomenèje pavyzdžių. Keli informantai atkreipè dèmesị ị karinio rengimo (mokymo) inovacijas, nes, jų nuomone, labai svarbu taikyti šiuolaikiškas mokymo sistemas tiek vykdant individualųjį, tiek kolektyvinị rengimą. Stebètina, kad šias įžvalgas pateikè rezervo ir atsargos karininkai. 
Darytina prielaida, kad jie turi skirtingos patirties, kas jiems leidžia matyti kitus aspektus. Keturi iš šešių informantų teigè, kad dronai yra plačiai taikomi LK ir jie keičia karybą. Atskiros iniciatyvos mokyti dronų teorijos bei bandyti taikyti praktinèse pratybose yra ịgyvendinamos, tačiau sisteminio požiūrio pasigendama. Tyrimo dalyvių atsakymai galimai padeda suprasti, kad visi dalyviai mato technologinę pažangą LK, darytina prielaida, kad ji tik didès ir būsimų karininkų kvalifikacijos struktūra ir turinys būtinai turi atliepti technologinius pokyčius. Keičiant kvalifikacijos struktūrą ir turinį rekomenduojama pasitelkti skirtingų sričių specialistus, nes jie gali parodyti nematomas būtinų pokyčių puses.

Technologinès naujovės, kurios, tikimasi, bus taikomos LK ateityje. Tyrimo metu siekta nustatyti, kokios technologinès naujovès gali pasiekti LK ir būti aktualios ateityje. Atitinkamai reikètų vertinti ir jų integravimą ị karininkų rengimo procesą. Kategoriją „Technologinès naujovès, kurios, tikimasi, bus taikomos LK ateityje" sudaro keturios subkategorijos (žr. 8 lentelę).

8 lentelė. Technologinès naujovès, kurios, tikimasi, bus taikomos LK ateityje

\begin{tabular}{|c|c|c|}
\hline Kategorija & Subkategorija & Irodantis teiginys \\
\hline & $\begin{array}{c}\text { Tinklų } \\
\text { blokavimas, } \\
\text { elektroninė } \\
\text { kova, signalų } \\
\text { maskuotė }\end{array}$ & 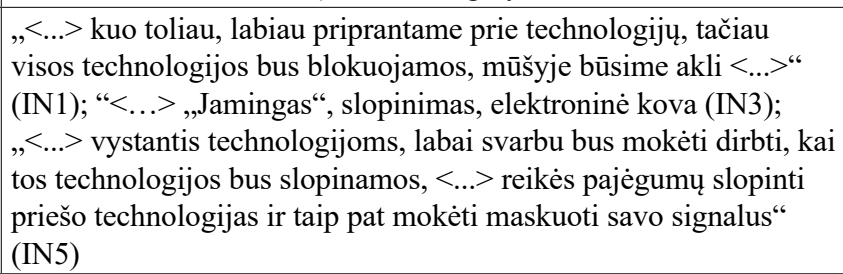 \\
\hline $\begin{array}{l}\text { Technologinès } \\
\text { naujovès, } \\
\text { kurios, } \\
\text { tikimasi, bus } \\
\text { taikomos } \\
\text { LK ateityje }\end{array}$ & $\begin{array}{c}\text { Dronu, } \\
\text { robotikos } \\
\text { sistemų } \\
\text { panaudojimas }\end{array}$ & 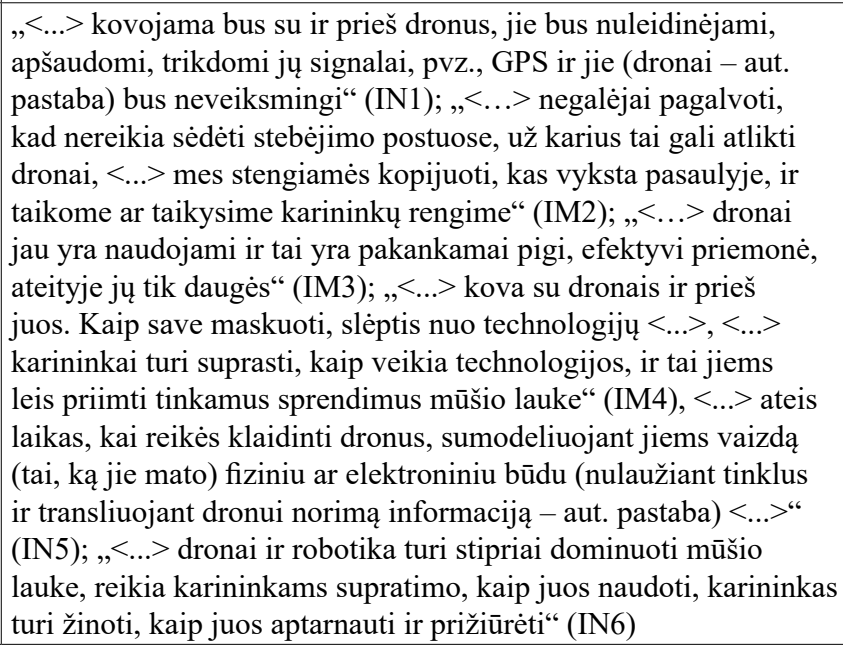 \\
\hline
\end{tabular}




\begin{tabular}{|c|c|c|}
\hline \multirow[t]{2}{*}{$\begin{array}{l}\text { Technologinès } \\
\text { naujovès, } \\
\text { kurios, } \\
\text { tikimasi, bus } \\
\text { taikomos } \\
\text { LK ateityje }\end{array}$} & $\begin{array}{l}\text { Naujos } \\
\text { ekipuotės, } \\
\text { papildytos } \\
\text { realybės, } \\
\text { apsaugos } \\
\text { priemoniu } \\
\text { naudojimas }\end{array}$ & 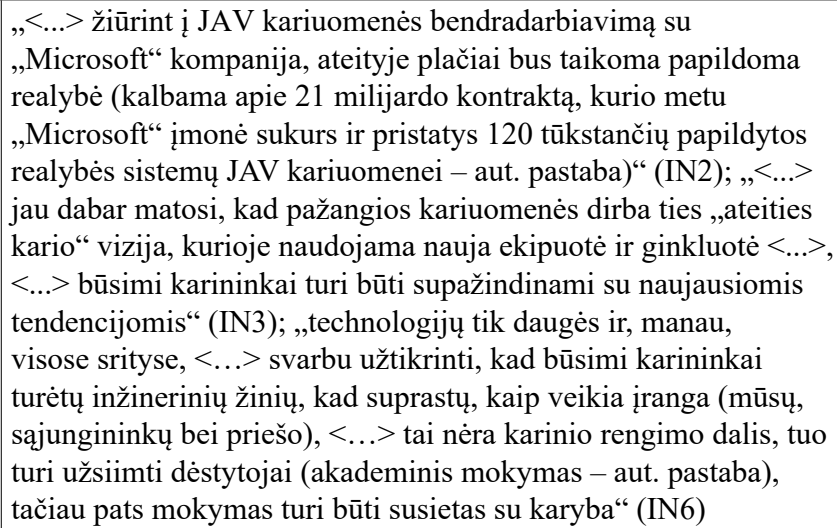 \\
\hline & $\begin{array}{c}\text { Debesijos } \\
\text { naudojimas }\end{array}$ & 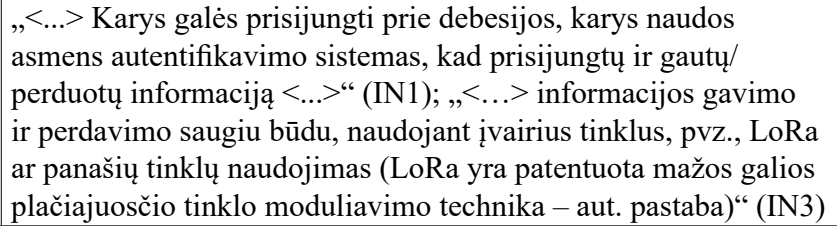 \\
\hline
\end{tabular}

Šaltinis: sudaryta autoriaus.

Apibendrinus tyrimo dalyvių nuomones apie technologines naujoves, kurios, tikimasi, bus taikomos LK ateityje, pastebima, kad dauguma jų išskyrẻ dronus ir robotikos sistemas. Informantai įsitikinę, kad dronai, robotai turès didelę ịtaką ateities mūšiuose. Taip pat ateities mūšio lauke tikimasi pamatyti daugiau 4-osios pramonès revoliucijos požymių, pvz., naudojamų ịvairių informaciją renkančių ir siunčiančių davikliu, kurie bus sujungti ị tinklą. Dèl to vyks elektroninè kova, siekiant juos slopinti ir (ar) keisti jų gaunamą ir siunčiamą informaciją. Būsimiems karininkams bus pavaldūs ne tik kariai, bet ir autonominiai robotai, kas suponuoja mintį, kad kariuomeneje rasis daugiau kvalifikuoto personalo, kuris specializuosis ,protingos“ technikos priežiūros srityje, kas pareikalaus jau visai kitokio pasirengimo. Taip pat galima daryti prielaidą, kad karininkų specialistų rotacija bus ribota dèl ịrangos sudètingumo ir specializacijos.

Didžiausią profesinę ir gyvenimišką patirtį turintis tyrimo dalyvis teigia pastebèjęs, kad karinè vadovybè nekreipia dėmesio ị technologinį karininkų parengimą, jis taip pat akcentavo, kad būtina suvienyti universitetinio ir karinio ugdymo pastangas ir ieškoti sinergijos, nes galimai vien karinio rengimo metu (laiku) bus neimanoma išplèsti programos, reikès tai sinchronizuoti su universitetinėmis studijomis.

Būtini karininkų švietimo ir rengimo pokyčiai, atliepiantys technologinę pažangą. Atliekant tyrimą siekta nustatyti, kokius universitetinių studijų ir karinio rengimo pokyčius, atliepiančius technologinę pažangą, siūlo informantai. Kategoriją „Būtini karininkų švietimo ir rengimo pokyčiai, atliepiantys technologinę pažangą" sudaro trys subkategorijos (žr. 9 lentelę). 
9 lentelè. Būtini karininkų švietimo ir rengimo pokyčiai, atliepiantys technologinę pažangą

\begin{tabular}{|c|c|c|}
\hline Kategorija & Subkategorija & Irrodantis teiginys \\
\hline \multirow{3}{*}{$\begin{array}{c}\text { Būtini } \\
\text { karininkų } \\
\text { švietimo } \\
\text { ir rengimo } \\
\text { pokyčiai, } \\
\text { atliepiantys } \\
\text { technologinę } \\
\text { pažangą }\end{array}$} & $\begin{array}{c}\text { Turi būti sistema, } \\
\text { kaip keičiamos } \\
\text { karininkų } \\
\text { rengimo } \\
\text { programos }\end{array}$ & 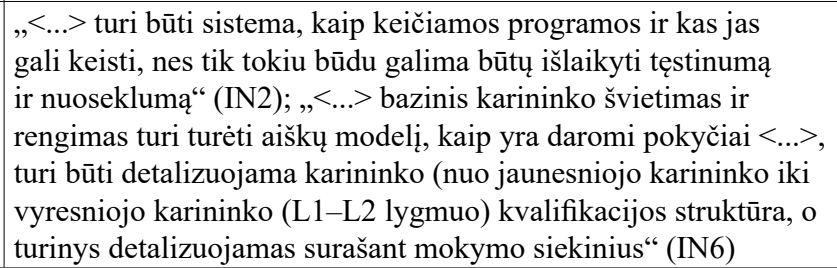 \\
\hline & $\begin{array}{c}\text { Kompiuterinis } \\
\text { (technologinis) } \\
\text { raštingumas }\end{array}$ & 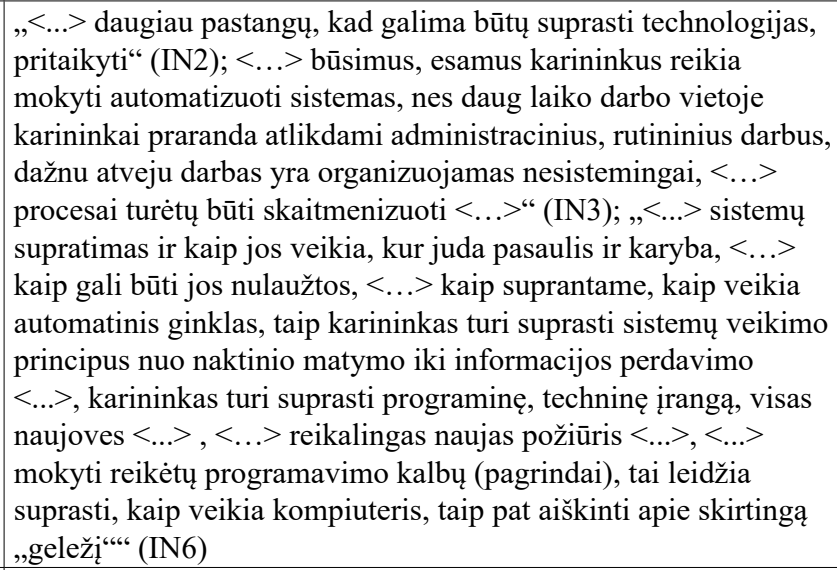 \\
\hline & $\begin{array}{l}\text { Karininko } \\
\text { ugdymas turi būti } \\
\text { sinchronizuotas } \\
\text { tarp akademinių } \\
\text { dalykų ir karinio } \\
\text { rengimo (vienam } \\
\text { kitą papildant) } \\
\end{array}$ & 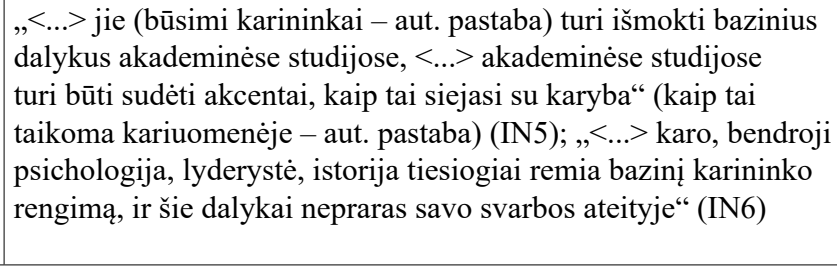 \\
\hline
\end{tabular}

Šaltinis: sudaryta autoriaus.

Apibendrinus tyrimo dalyvių nuomones apie karininkų švietimo ir rengimo būtinuosius pokyčius, atliepiančius technologinę pažangą, pastebima, kad tyrimo rezultatai pasiskirste ị tris subkategorijas. Pirmiausia tyrimo dalyviai išskyrè poreikị KAS sukurti ir taikyti holistinị karininkų švietimo modelị (Melnikovas, 2019), kuris turètų užtikrinti naujojo karininkų švietimo ir rengimo modelio taikymą, dèl kurio kistų karininkų kvalifikacijos struktūra ir turinys. Tačiau galima suprasti, kad tyrimo dalyviai pastebi, jog karininkai jau dabar stokoja kompiuterinio (technologinio) raštingumo žinių, ir siūlo ieškoti būdų, kaip karininkų švietimą ir rengimą tinkamai būtų galima derinti prie universitetinių studijų ir profesinio karinio rengimo. Akademinès studijos ir karinis rengimas turi papildyti vienas kitą, nes profesinio rengimo metu išmokstama, „kaip“, o vykdant švietimą (universitetini, profesinị) atsakoma, „kada“ taikyti jau ịgytus ịgūdžius (kompetencijas). 


\section{Išvados}

1. Naujų karininkų švietimo ir rengimo modelių poreikį lemia kylančios grèsmès ir „išmoktos pamokos“. Iprastai akademinès žinios teikiamos vykdant švietimą, o praktiniai ịgūdžiai - profesinį rengimą. Karininkų švietimo ir rengimo modelių „Jenos“, „Folklando“, „Kosovo“ ir „Nacionalinio gynybos universiteto“ analizè parodè kintančius reikalavimus karinèms pajègoms atsižvelgiant ị skirtingo pobūdžio grèsmes. NATO linkusi rinktis „Nacionalinio gynybos universiteto“ karininkų švietimo ir rengimo modelị, kuris aiškiai rodo, kad reikalavimai karininkų ugdymui nuolatos kyla. Jau šiuo metu tikimasi, kad karininkai gebės vadovauti sudètingoms operacijoms tarptautinio kontingento sudètyje, prireikus vykdys specifines užduotis, pradedant nuo taikos palaikymo, humanitarinès pagalbos teikimo misijų ir baigiant gynybinèmis ir puolamosiomis operacijomis, suprasdami ne tik nacionalinị, bet ir pasaulinį geopolitinị kontekstą.

2. Sąvokos „4-oji pramonès revoliucija“, „kibernetinès fizinès sistemos (CPS)“, „,sumanioji gamyba“, ,,skaitmeninè transformacija“ vartojamos tiesiogiai ir kaip sinonimai. Pabrěžtina, kad 4-oji pramonès revoliucija smelkiasi ị daugelị sektorių, o gynybos sektorius nèra išimtis, nes jame, kaip ir pramonèje, reikalingas didesnis efektyvumas, kompetencija ir konkurencingumas. Šie rodikliai pasiekiami sujungiant fizinị ir skaitmeninị pasaulius ị visumą, ịprastai naudojant internetą. $\mathrm{O}$ 4-oji pramonès revoliucija jungia greitaji internetą, mažus, bet galingus jutiklius, dirbtinị intelektą, kibernetines fizines sistemas, didžiuosius duomenis ir jų analitiką, autonominius robotus, gebančius prisitaikyti, kibernetinį saugumą užtikrinančius įrankius, debesijos paslaugas, papildytą realybę, daiktų internetą (IoT) ir dar daug kitų sudedamujų ir jungiamųjų elementų. Sparčiai vystantis technologijoms ir atsirandant vis naujų jų derinių, galimas grèsmių ir galimybių mastas nèra plačiai ịvertinimas, tačiau 4-osios pramonès revoliucijos naujovès leidžia vis įvairesniais būdais kenkti valstybėms ar individams.

3. Surinktų duomenų analizè leidžia teigti, kad bazinio karininkų rengimo programos nuolatos kinta, įžvelgiami oficialūs ir neoficialūs pokyčiai, vieni jų įtvirtinami keičiant programas, kiti vyksta bandant prisitaikyti prie esamos realios situacijos. Tyrimo dalyviai išskyrè šešis veiksnius, lemiančius programų pokyčius. Pažymètina, kad tyrimo dalyvių atsakymai priklausè nuo informantų kuruojamų sričių ir tarnybos (darbo) KAS patirties. Dauguma informantų nurodè, kad mokymo reikalavimų specifikacija yra pagrindinis dokumentas, nuo kurio formaliai prasideda pokytis ir yra keičiama bazinio karininkų rengimo programa. Apklausos metu nebuvo gauta ịrodymų, kad programų pokyčiai būtų nulemti naujųjų technologijų skvarbos. Informantai atsakymuose neišskyrè pokyčių, kuriuos lemia karybos skaitmenizavimas.

Tyrimo metu visi infomantai pateikè technologinių naujovių, taikomų pastaruosius dešimt metų LK, pavyzdžių. Keli tyrimo dalyviai akcentavo karinio rengimo (mokymo) inovacijas, nes, jų nuomone, labai svarbu taikyti šiuolaikiškas moky- 
mo sistemas tiek vykdant individualųji, tiek kolektyvinį rengimą, nes jos itin gerina išmokimo kokybę.

Visi dalyviai mato technologinę LK pažangą, todèl darytina prielaida, kad ji tik didès, todèl būsimų karininkų kvalifikacijos struktūra ir turinys būtinai turi atliepti technologinius pokyčius. Tyrimo dalyvių sociodemografinių charakteristikų ir jų atsakymų turinio analizė atskleidè, kad ịvairesnès patirties turintys informantai pateikè ịvairesnius atsakymus, todèl rekomenduotina keičiant kvalifikacijos struktūrą ir turinị pasitelkti skirtingų sričių specialistus, nes jie gali parodyti nematomas būtinų pokyčių puses.

Apklausus tyrimo dalyvius apie ateities technologines naujoves, kurios, tikimasi, bus taikomos LK ateityje, pastebèta, kad dauguma jų išskyre dronų, robotikos skvarbą. Mūšio lauke bus galima pamatyti 4-osios pramonès revoliucijos metu vystomas technologijas. Tikimasi, kad būsimi karininkai bus atsakingi už naujovių diegimą LK ir vadovaus ne tik pavaldiems kariams, bet ir autonominiams robotams, kas suponuoja mintị, jog kariuomeneje rasis daugiau kvalifikuoto personalo. Šis personalas specializuosis ,protingos“ technikos priežiūros srityje, o tai pareikalaus jau visai kitokio pobūdžio kompetencijų.

Tyrimo dalyviai jau dabar pastebi, kad karininkai stokoja kompiuterinio (technologinio) raštingumo žinių ir įgūdžių, ir siūlo ieškoti būdų, kaip karininkų švietimą ir rengimą tinkamai derinti prie universitetinių studijų ir profesinio karinio rengimo. Informantai, suprasdami būtinybę tobulinti būsimų karininkų kvalifikacijos struktūrą ir turinị, pasisakè už sisteminị požiūrị ị programų kaitą bei būtiną universitetinio ir profesinio ugdymo sinergiją, nes šiuo metu tai yra atskiri blokai ir KAS aukščiausioji vadovybè nesinchronizuoja universitetinių studijų ir karinio rengimo turinio.

\section{Literatūra}

Avis, J. (2018). Socio-technical imaginary of the fourth industrial revolution and its implications for vocational education and training: a literature review. Journal of Vocational Education and Training, 70(3), 337-363, https://doi.org/10.1 080/13636820.2018.1498907

Bryman, A. (2008). Social Research Methods (3rd ed.). Oxford University Press.

Carl von Clausewitz. (1989). On War (P. P. Michael Howard, Ed.). Princeton University Press.

Caselli, F. (1999). Technological revolutions. American Economic Review, 89(1), 78-102, https://doi.org/10.1257/aer.89.1.78

Clark, B; Patt, D.; Schramm, H. (2020). Mosaic Warfare. Exploiting artificial intelligence and autonomous systems to implement decision-centric operations. In Center for strategic and budgetary assessmen, https://csbaonline.org/uploads/ documents/Mosaic_Warfare_Web.pdf 
Foot, P. (2001). European military education today. Baltic Defence Review, 5, https://www.baltdefcol.org/files/docs/bdreview/bdr-2001-5-04.pdf

Gell, H., Paile-Valvo, S., \& Zambas, S. (2018). European education and training for young officers. European Initiative for the Exchange of young Officers, inspired by Erasmus 2 nd Edition.

Generolo Jono Žemaičio Lietuvos karo akademijos statutas, Žin., 1999, Nr. 69-2196.

Gražytė-Miliukienè, G., \& Prakapienè, D. (2012). Karininkų profesionalumo ugdymas: problemos ir tobulinimo galimybės. Ekonomika ir vadyba: aktualijos ir perspektyvos, $28,177-186$.

Holth, T., \& Boe, O. (2017). Enhancing the Leadership Communication Skills of Norwegian Military Officers. Arts and Social Sciences Journal, 08(01), 4-9, https://doi.org/10.4172/2151-6200.1000250

Joint Analysis \& Lessons Learned Centre. (2016). The NATO Lessons Learned Handbook (Third Edition).

Keagle, J. M., \& Petros, T. G. (2010). Building Partner Capacity Through Education: NATO Engagement with the Partnership for Peace. Connections, 10(1), 46-63.

Kenney, S. (1996). Professional Military Education and the Emerging Revolution in Military Affairs. Air \& Space Power Journal, 10(3), 50.

Kurt, R. (2019). Industry 4.0 in Terms of Industrial Relations and Its Impacts on Labour Life. Procedia Computer Science, 158, 590-601, https://doi. org/10.1016/j.procs.2019.09.093

Lasi, H., Fettke, P., Kemper, H. G., Feld, T., \& Hoffmann, M. (2014). Industry 4.0. Business and Information Systems Engineering, 6(4), 239-242, https://doi. org/10.1007/s12599-014-0334-4

Liao, Y., Deschamps, F., Loures, E. de F. R., \& Ramos, L. F. P. (2017). Past, present and future of Industry 4.0 - a systematic literature review and research agenda proposal. International Journal of Production Research, 55(12), 36093629, https://doi.org/10.1080/00207543.2017.1308576

Libel, T. (2016). European Military Culture and Security Governance. Routledge, Taylor and Francis Group.

Libel, T. (2019). From the sociology of the (military) profession to the sociology of (security) expertise: the case of European national defence universities. Defence Studies, 19(1), 62-84, https://doi.org/10.1080/14702436.2018.1562910

Lietuvos karinių pajègų rengimo doktrina. (2013). Lietuvos kariniu pajégy rengimo doktrina (D-LK-07) (G. Sadaitis, Ed.; Patikslint). Mokymo ir doktrinu valdyba, https://kariuomene.kam.lt/lt/kariuomenes_struktura/mokymo_ir_doktrinu_ valdyba/lk_doktrinos.html

Lietuvos Respublikos krašto apsaugos sistemos organizavimo ir karo tarnybos įstatymas, Žin., 1998, Nr. 49-1325.

LKA. (2018). Generolo Jono Žemaičio Lietuvos karo akademijos strategija. 
2018-2024 metai.

Meese, M., \& Calkins, S. (2006). Back to the future: Transforming the army officer development system. In Forum (Vol. 4, Issue 1, pp. 25-39). Walter de Gruyter $\mathrm{GmbH}$, https://doi.org/10.2202/1540-8884.1117

Melnikovas, A. (2019). Officer education policy development in the context of the changing european security and defence identity. 6131, 79-94.

Monostori, L., Kádár, B., Bauernhansl, T., Kondoh, S., Kumara, S., Reinhart, G., Sauer, O., Schuh, G., Sihn, W., \& Ueda, K. (2016). Cyber-physical systems in manufacturing. CIRP Annals, 65(2), 621-641, https://doi.org/10.1016/j. cirp.2016.06.005

Orsi, D. (2017). Professional Military Education and Broadening Assignments A Model for the Future. In JFQ (Vol. 86).

Park, K. W. (2010). Assembly Line to Custom Design: Reforming the Officer Development System.

Paul Price, B. A., \& Smith, J. M. (2004). Genesis and evolution of the united states air force academy's officer development system.

Pfeiffer, S. (2015). Effects of Industry 4.0 on vocational education and training, http://epub.oeaw.ac.at/ita/ita-manuscript/ita_15_04.pdf

Prisecaru, P. (2016). Challenges of the fourth industrial revolution. Knowlidge Horizons - Economics, 8(1), 57-62. https://doi.org/10.23683/2073-66062019-17-2-6-22

Prisecaru, Petre. (2016). Challenges of the fourth industrial revolution. Knowledge Horizons - Economics, 8(1), 57-62, www.orizonturi.ucdc.ro

Puzinavičius, B. (2006). Karininkas - pedagogas ir vadas. Karo archyvas, 21, 67-116.

Schwab, K. (2016). The Fourth industrial revolution, https://doi.org/ 10.16309/j.cnki.issn.1007-1776.2003.03.004

Šlekys, D. (2015). Maslaus Vyčio beieškant: lietuviškos karinès minties raida ir būkle po nepriklausomybès atkūrimo (1990-2014): Monografija (G. Vitkus, Ed.). Lietuvos kariuomenès karo kartografijos centras.

Teper, Y. (2016). Official Russian identity discourse in light of the annexation of Crimea: national or imperial? Post-Soviet Affairs, 32(4), 378-396, https://doi. org/10.1080/1060586X.2015.1076959

Vaidya, S., Ambad, P., \& Bhosle, S. (2018). Industry 4.0 - A Glimpse. Procedia Manufacturing, 20, 233-238, https://doi.org/10.1016/j.promfg.2018.02.034

$\mathrm{Xu}$, L. da, Xu, E. L., \& Li, L. (2018). Industry 4.0: State of the art and future trends. International Journal of Production Research, 56(8), 2941-2962, https:// doi.org/10.1080/00207543.2018.1444806

Xu, M., David, J. M., \& Kim, S. H. (2018). The fourth industrial revolution: Opportunities and challenges. International Journal of Financial Research, 9(2), 90-95, https://doi.org/10.5430/ijfr.v9n2p90

Žigaras, F. (2018). Karininku rengimo ir ju kvalifikacijos kelimo sistema 
1919-1940: Vol. 1 dalis (A. Algirdas, Ed.). Generolo Jono Žemaičio Lietuvos karo akademija.

Žigaras, F. (2019). Vytauto didžiojo karininkų kursai. Šiuolaikinès visuomenès ugdymo veiksniai, 4.

Žydžiūnaitè, V. (2011). Baigiamojo darbo rengimo metodologija, http:// www.esparama.lt/es_parama_pletra/failai/ESFproduktai/2012_Baigiamojo_darbo_metodologija.pdf

Žydžiūnaite, V., \& Sabaliauskas, S. (2017). Kokybiniai tyrimai: principai ir metodai: vadovélis socialiniu mokslu studiju programu studentams. Vaga. 


\title{
LITHUANIAN BASIC OFFICERS TRAINING QUALIFICATIONS CHANGES IN THE CONDITIONS OF THE 4TH INDUSTRIAL REVOLUTION DEVELOPMENT
}

\author{
Laurynas Česūnas \\ General Jonas Žemaitis Military Academy of Lithuania
}

\section{Summary}

The aim of the publication is to reveal the necessary changes in the basic structure and content of officers' qualifications arising from the digitization of business processes and other aspects of the development of Industry 4.0. The article discusses the reasons for the change in officers' education and training qualifications, presents the officer education and training model, the primary input of which is "emerging threats", justifies that all fourofficer education and training models "Jena", "Falkland Islands", "Kosovo" arose when the troops faced challenges (threats), all changes are usually reactive in nature. The article reveals "Industry 4.0", "Industrial Revolution 4" and other directly used concepts, presents the components/features of "Industry 4.0": high-speed Internet, powerful sensors, artificial intelligence, cyber-physical systems, and a myriad of other components and connectors. With the rapid development of technology and the creative discovery of new combinations of them in unpredictable ways, the potential scale of threats and opportunities is not widely assessed, and future officers should begin to prepare for new challenges now. The empirical part of the article is based on a survey of the opinion of soldiers (non-commissioned officers, officers) serving/retired, which was conducted in 2021 at the Lithuanian Military Academy. The study found that the structure and content of the basic officer training program is constantly changing, formal and informal changes are seen, some changes are consolidated by changing the programs, others take place to adapt to the current, real situation. The informants revealed six factors that led to changes in the programs, all of which are thought to be of a reactionary nature. The survey did not provide evidence that program changes would be driven by the future penetration of future technologies. During the research, all informants provided examples of technological innovations and the application of innovations in the Lithuanian Armed Forces. Most of the informants said that drones are widely used in LAF and drones are changing the war, but there is no formal training in training future officers. The informants confirmed that they are monitoring the penetration of new technologies in LAF, and they also see the need to change/supplement the curriculum of future officers' education and training so that future officers receive technological training. It was also emphasized that it was necessary to combine academic and military education and training efforts and seek synergies in the training of fully-fledged future officers. 


\section{AUTORIAUS LYDRAŠTIS}

Autoriaus vardas, pavardè: Laurynas Česūnas

Mokslo laipsnis ir vardas: magistras, humanitariniai mokslai

Darbo vieta ir pareigos: Generolo Jono Žemaičio Lietuvos karo akademijos Lyderystės ir metodinio rengimo centro vyr. metodininkas

Autoriaus mokslinių interesų sritys: edukologija, andragogika, karių mokymo metodika, pažangūs mokymo metodai, šaudymo iš pistoleto metodikos

Telefonas ir el. pašto adresas: laurynasc@gmail.com

\section{AUTHOR'S COVER LETTER}

Author's name and surname: Laurynas Česūnas

Academic degree and name: Master of Public Security and Defence

Workplace and position: General Jonas Žemaitis Military Academy of Lithuania, Leadership and Methodological Development Centre, Senior Methodologist

Author's research interests: educational science, andragogy, military training methodology, advanced training methods, pistol shooting techniques.

Telephone and e-mail address: laurynasc@gmail.com 